\title{
Review Article \\ Oxidative Stress in Fish: A Review
}

\author{
S. Chowdhury, S. K. Saikia* \\ Aquatic Ecology and Fish Biology Laboratory, Department of Zoology, Centre for Advanced \\ Studies, Visva-Bharati University, Santiniketan, West Bengal, India
}

Received 9 June 2019, accepted in final revised form 18 September 2019

\begin{abstract}
Apart from its beneficial properties of oxygen to cellular functions, it can cause some undesirable damages by the formation of ROS which can be neutralized by the formation of enzymatic and non-enzymatic antioxidants. Like any other vertebrate, these damages can be seen in fish which are exposed to various oxidative stressors. In fish, it may be brought by a variety of chemicals (pesticides, insecticides etc.), or environmental factors ( $\mathrm{DO}, \mathrm{pH}$, temperature, salinity, etc) affecting different biological processes in fish. The present review discusses some of such stressors and their effects on fish from a wide range of literature available across last four decades. The metabolic pathways involved in terms of energy homeostasis and ATP production during stress exposure in fish is a new addition here, and has been addressed to some extent in case of temperature and salinity stress.
\end{abstract}

Keywords: Oxidative stress; Reactive oxygen species; Free radical; Antioxidants; Hypoxia; HIF $1 \alpha$.

(C) 2020 JSR Publications. ISSN: 2070-0237 (Print); 2070-0245 (Online). All rights reserved doi: http://dx.doi.org/10.3329/jsr.v12i1.41716 J. Sci. Res. 12 (1), 145-160 (2020)

\section{Introduction}

Oxygen is the major biological acceptor of electrons which serves a vital role in cellular functions. However, in spite of its beneficial properties, it contributes to the undesirable formation of reactive oxygen species (ROS) such as superoxide, hydrogen peroxide and hydroxyl radical [1]. ROS can be of two types, free radicals and non-radicals. Molecules containing one or more unpaired electrons and thus giving reactivity to the molecule are called free radicals and when they share their unpaired electrons, non-radicals are formed [2].

There may be two sources of ROS, endogenous sources or exogenous sources. Non enzymatic endogenous sources of ROS may be Fenton's and Haber's reactions, or enzymatic like monoamine oxidase, Nicotinamide adenine dinucleotide phosphate

\footnotetext{
* Corresponding author: surjyasurjya@gmail.com
} 
hydrogen (NADPH) oxidase, Xanthine oxidoreductase, arachidonic acid and Cytochrome p450 oxidase. Some other endogenous sources of ROS are mitochondria (through the electron transport chain), endoplasmic reticulum, peroxisomes, lysosomes and receptor mediated ROS generation [3].

In general, ROS have got various damaging effects which involve mainly the structural modification of lipids, proteins and nucleic acids within the cellular compartments [4]. Lipid peroxidation is a common example of ROS induced damage where the polyunsaturated fatty acids are prone to free radical attack and begins a chain reaction [5]. ROS exposed cells are very much prone to frequent DNA damage. They may activate the nucleases and there may be direct reaction of hydroxyl radicals with the DNA resulting distinct pattern of chemical modification [6]. The ROS plays some important roles in the functioning of immune system, then maintains a redox balance and also has implications in activating various cellular signalling pathways. As excess of ROS generation damages cellular lipids, proteins, nucleic acids, membranes and organelles which in turn can lead to activation of cell death processes such as apoptosis [7]. Even, polysaccharides such as hyaluronic acid can be degraded by oxidative attack [8]. Oxygen species are one of the key participants in damages caused by neurodegenerative processes which include cell death, motor neuron diseases and axonal injury causing Alzheimer's, Parkinson's and Huntington's like diseases in mammals [9].

To minimize the damaging effects of ROS, organisms have enzymatic and nonenzymatic antioxidant defences. These are depicted in the Table 1.

Table 1. Enzymatic and Non-enzymatic antioxidant defenses (modified from Finaud et al. [10]).

\begin{tabular}{ll}
\hline Enzymatic Antioxidants & Non-enzymatic Antioxidants \\
\hline Superoxide dismutases & Vitamin E \\
Catalase & Vitamin C \\
Glutathione peroxidises & $\beta$ carotene \\
Glutathione reductase & Vitamin A \\
Glutathione-S-transferases & Glutathione \\
& Flavonoids \\
& Thiols \\
& Coenzyme Q \\
& Uric acid \\
\hline
\end{tabular}

These antioxidants protect the cellular components from oxidative damage exerted by ROS. The imbalance between the generation and the neutralization of ROS by these antioxidant mechanisms within the organism is called oxidative stress which has become an important subject for study in both terrestrial and aquatic toxicology [11].

\section{Fish and Oxidative Stress}

Like other animals, the contaminant-stimulated ROS production results in oxidative damage in fish, initiating a mechanism of toxicity on exposure to pollution. Moreover, stress can also be induced from other sources such as environmental hypoxia and use of 
ozonization in aquaculture [12]. Changes in temperature, oxygen and salinity can cause stress under natural and artificial conditions via induction of misbalance between ROS production and elimination. The role of transition metal ions, such as copper, chromium, mercury, arsenic, and pesticides, namely insecticides, herbicides, and fungicides along with oil products induce oxidative stress on fish [4]. There are fish specific stressors, like capture, transport and handling of fish, crowding of fishes, hyper or hypothermia, hypoxic conditions, hyper or hypo salinity, malnutrition and contaminants of various types. These stressors induce stress response hampering the normal morphology and physiology of the fish [13]. Fish exposed to river polluted by thermal power plant effluent become hypoglycemic, hyperlipidemic and hypercholesterolemic and induce immune system making the fish weak and vulnerable to diseases [14]. Handling of fish during transportation and the stocking density of fish during caging are also some important factors that may affect the health of fish resulting in their reduced growth [15]. Further, the growth of juveniles like fry and fingerlings are affected, under chronic exposure to stress. Fry of rainbow trout (Oncorhynchus mykiss) shows a change in antioxidant status and oxidative stress parameters when exposed to selenium [16]. Toxicity of methyl mercury chloride and mercuric chloride also affects the health and growth of fry and fingerlings of $O$. mykiss [17]. Mishandling of the fishes reduces its fecundity, even leading to extinction of some of the fish species [18].

In general, any kind of stressor can affect reproduction, gamete quality and progeny of a fish. Studies revealed that different taxa of fishes have different levels of tolerances to stress i.e. the severity may vary depending on the species [19]. Even, during the last 10 years, knowledge on sensitivity of reproduction of fish to stress has emerged as significant information in aquaculture. For example, the exposures of chemicals like duroquinone to the spermatozoa of common carp (Cyprinus carpio) impair its reproduction through oxidative stress [20]. The effect of $\mathrm{Cu}$ was linked to the reproduction of fathead minnow (Pimephales promelas) and from then the bioassay of any stressor had been taken into account for the whole life cycle of the fish with special reference to reproduction [21]. Thus, it is evident that deteriorated aquatic environment greatly affect the growth and development of fish. Further, the primary and visible effect of pollution led alterations in aquatic environment is the deteriorated $\mathrm{DO}, \mathrm{pH}$, temperature, etc. that exert significant effect on fish body and its biology of reproduction and growth, which cumulatively affect the total production of fish.

\section{Aquatic Source Based Oxidative Stress in Fish}

The overall sources to induce oxidative stress in fish may be discussed under two broad groups:-

\subsection{Chemotoxicity induced oxidative stress in fish}


As already mentioned, there are a lot of stressors in the aquatic environment and several studies have shown their effects on the normal physiologic conditions of the fish. A variety of chemicals like insecticides, pesticides, xenoestrogens, etc. affect the fish causing impairment of its metabolism [22,23]. The chemical 2,4-D herbicide affects the acetylcholinesterase activity and metabolic parameters of Piava freshwater fish (Leporinus obtusidens) [24]. Polluted petroleum exploration area in Delta state, Nigeria showed altered biochemical parameters in Clarius gariepinus indicating that the fish suffered from stress in their normal habitat due to exposure to petroleum effluents released in the habitat [25]. Heavy metals are also a high and potential source of stressors in the aquatic environment. Studies evidenced that heavy metals have strong impacts on the hematological parameters of C. carpio and Channa punctatus [26,27]. The $\mathrm{Cd}$ contamination in the aquatic environment exposed to fish also alters the oxidative stress biomarkers and induces aggressive behavior in the fish [28]. It was observed that fish exposed to highly polluted water containing toxic metals like $\mathrm{Cr}$ and lead has lower survival rates [29]. Chemicals like vanadate oligomers can also induce oxidative stress response in cardiac muscles of toad fish, Halobactrachus didactylus [30]. Zebrafish (Danio rerio) exposed to subchronic atrazine also shows an increased oxidative stress response [31]. Xenoestrogens like bisphenol-A affects the histopathology of liver, kidney and gills of Indian major carp Catla catla and the larvae of some rare minnows (Gobiocypris rarus) [32, 33]. Alteration of cholinesterase activity and other stress markers have been reported in the tropical reef fish (Acanthochromis polyacanthus) exposed to chemical called chlorpyrifos [34]. Ag nanoparticles can also induce oxidative stress and apoptosis in the liver of an adult D. rerio [35]. Oxidative stress markers get altered in fishes like Astyanax sp and D. rerio exposed to urban and agricultural effluents in the Brazilian Pampa biome [36]. Chronic exposure to endosulfan induces oxidative stress in the fresh water cyprinid crucian carp, Carassius carassius [37,38]. There is an induction of antioxidant response and oxidative stress associated genotoxicity as well as histopathological alteration in two commercial fish species due to heavy metal exposure in northern India [39]. D. rerio embryos exposed to acute and sublethal copper oxide nanoparticles cause oxidative stress and teratogenicity [40]. Again, a chronic ammonia exposure to the juveniles of Nile tilapia (Oreochromis niloticus) alters antioxidants in liver and white muscles resulting in oxidative stress [41]. Thermal power plant effluent can also alter oxidative stress response in fishes [14]. Exposure of goldfish (Carassius auratus) to $\mathrm{Cr}$ affects the expression of antioxidant enzymes and generation of free radicals showing its oxidative stress response [42]. Analysis of oxidative stress biomarkers in Notopterus notopterus tissues from Mahanadi River revealed concentration of heavy metals in the river resulting in oxidative stress [43]. DNA damage and altered oxidative stress biomarker is the effect of glycophosate based herbicide exposure to the fresh water fish C. punctatus [44]. Studies were also performed on biomarkers of oxidative stress in Wallago attu in Yamuna river [45]. Protein carbonyls, which is also a novel biomarker of oxidative stress alters when exposed to pesticides [46]. Another chemical called deltamethrin changes the oxidative stress biomarkers in fresh water fish 
C. punctatus, Bloch [47]. Both $\mathrm{V}$ and Cd have in vivo effects in teleost fish indicating oxidative stress response in these fishes [48]. So, there are several chemicals in the aquatic environment whose exposure to the fish and the aquatic animals causes severe oxidative damage to the organisms.

\subsection{Environment induced oxidative stress in fish}

Apart from chemicals and heavy metal toxicity there are some other ambient conditions in the aquatic system that can even lead to severe oxidative damage induced stress in fish. These are mainly dissolved oxygen (DO), $\mathrm{pH}$ and temperature of the ambient water. Long term exposure to hypoxia or reduced oxygen in the ambience triggers antioxidant defence activities leading to high risk of oxidative stress. Studies have revealed that continuous exposure to low DO or hypoxic condition of water may be lethal to Panaeus monodon. Even, short term exposure to extremely low DO may also induce stress in the juveniles leading to its atrophied growth [49]. However, from species to species, such tolerance limit may vary. Reports showed that parr of Arctic charr (Salvelinus alpinus) can tolerate a much reduced DO concentration in its ambience [50]. The rate at which the DO reduces in the ambience is also a major factor of stress. O. mykiss experiences severe physiological and hematological stresses when exposed to lower DO in fish culture [51]. Under severe physiological stress, reduced swimming speed has been observed in atlantic cod (Gadus morhua) when exposed to progressive hypoxia in its ambience [52]. Studies on the tissues of $C$. auratus and Gobi (Perccottus glenii) have pointed out that both hypoxia and hyperoxia can induce oxidative stress which can be indicated by looking at the antioxidant enzyme response [53,54]. Not only DO, but changes in other abiotic factors, like temperature of the aquatic ambience can also adversely affect the health of aquatic organisms through inducing oxidative stress. Heat shock protein is one of the specific markers that get altered when organisms are exposed to heat stress [55]. Triebskorn et al. [56] has reported that induction in this heat shock proteins can lead to changes in the liver ultrastructure and alters the behavior of the fish. Even the change in temperature of the rivers and rapid warming of the climate adversely affect the survival of migrating adult sockeye salmon (Oncorhynchus nerka) from Fraser river [57]. On the other hand, lowering the temperature in the ambience also alters gene expression and lead to oxidative damages in the skeletal muscle of adult D. rerio [58]. Vinagre et al. [59], reported that altered temperature exert oxidative stress by studying lipid peroxidation and catalase activity in the muscles of juvenile seabass (Dicentrarchus labrax). Another important factor is the altered $\mathrm{pH}$ of the aquatic environment which may lead to severe oxidative damages in fish. Earlier, Fromm [60] revealed that acute exposure to acidic stress in the aquatic environment can even reduce fertility of the fish resulting in a decreased growth of the species. Both alkaline and acidic $\mathrm{pH}$ exerts negative effect on haematological parameters of three major carps C. catla, Labio rohita and Cirrhinus mrigala [61]. At the same time, acute acidic exposure to tilapia induces its p53 mediated oxidative stress and severe DNA damage in their blood cells [62]. Various other blood 
parameters have also been tested to assess the acidic stress in the habitat of a fish [63]. Some of the blood parameters have also been studied in D. rerio exposed to higher and lower $\mathrm{pH}$ ranges. $D$. rerio exposed to different water $\mathrm{pH}$ showed fluctuation in their blood glucose at different seasons. At the same time, their haematological parameters like WBC (White Blood Cell) and RBC (Red Blood Cell) count change with the change in $\mathrm{pH}$ ranges at different seasons [64].

\section{Effects of Oxidative Stress on Different Biological Processes in Fish}

\subsection{Effects of oxidative stress on the development of fish}

Zhu et al. [65] first studied the toxicity of stable Buckminster fullerene aggregates suspended in water (nC60) on the development of zebrafish using D. rerio as a vertebrate model. The survival, hatching rate, heartbeat, and pericardial edema of the embryo of $D$. rerio were noted and described within 96 h of exposure. Fullerol (a hydroxylated C60 derivative), delayed the development of $D$. rerio embryo and larva, decreased survival and hatching rates, and caused pericardial edema. Cypermethrin toxicity in D. rerio larva and embryo produces high levels of malondialdehyde (MDA). It even showed increased p53 gene expression as well as caspase 3 activity and was able to produce apoptosis through the involvement of caspases in D.rerio embryo [66]. Even, heavy metals in the ambience of fish larvae may cause their developmental deformities [67]. Early developmental stages of fish are very much sensitive to water pollution. Jezierska et al. [68] studied that heavy metals may have various effects on developmental processes during the embryonic period, which results in a reduction of both offspring quantity and quality. Water borne metals may accumulate in the gonads of spawners and adversely affect gamete production and viability, or exert direct toxic influence upon developing embryos. Heavy metals often induce a delay in the hatching process, premature hatching, deformations and death of newly hatched larvae. All these disturbances result in reduced numbers and poor quality of the larvae, which show small body size, high frequency of malformations and reduced viability. Exposure to mercury in medaka fish (Oryzias latipes) embryos causes severe developmental toxicity. Their phenotypes get altered including pericardial edema with elongated or tube heart, reduction of eye pigmentation, and failure of swim bladder inflation. Total RNA extraction from survivors to examine toxicity-related gene expression three days after exposure revealed that $\mathrm{Hg}$ exposure can markedly induced metallothionein and heme oxygenase-1 genes [69]. There are reports on toxicity due to metabolism of selenomethionine, which is the predominant form of $\mathrm{Se}$ in eggs of oviparous animals. When the Se load increases in the ambience of $O$. mykiss embryo, they have the capacity to transform selenomethionine to a form capable of producing superoxide radical [70]. Bioaccumulation of Se in eggs and larvae can also cause developmental deformities in some of the species of fish [71]. Developmental defects and embryo mortality was evidenced when an $O$. latipes at its early life stages was exposed to a zerovalent iron nano particle [72]. Di-n-butyl phthalate and diethyl phthalate exposure to 
the $D$. rerio embryos induce oxidative stress and expression of some cytokines resulting in enhancement of immune response in them [73].

\subsection{Effects of oxidative stress on the physiology and metabolic processes of fish}

There are reports on stress induced response of the hypothalamic-pituitary-interrenal axis and the resultant elevation of circulating corticosteroids. Stress, through the action of corticosteroids, may reduce immunocompetence by influencing lymphocyte numbers and antibody production capacity, and affects reproduction by altering levels and patterns of reproductive hormones that influence maturation. Stress may also alter metabolic scope in fish and affects growth which results in catabolic or gluconeogenic effect of corticosteroids [74]. In juvenile Chinook Salmon (Oncorhynchus tshawytscha), the plasma concentration of cortisol and glucose increased due to handling stress which was applied to them repeatedly at $3 \mathrm{~h}$ interval over $6 \mathrm{~h}$ [75]. Barton et al. [76] also reported that acid stress along with application of handling stress can increase the plasma cortisol level and decrease the plasma sodium levels in juvenile $O$. mykiss. The plasma glucose, cortisol and chloride levels were markedly altered when O. mykiss were reared in both wild and hatchery conditions [77]. Fish transport from one place to another also elevates plasma cortisol and, plasma glucose level, and also alters the balance of sodium and chloride ions in them [78]. Plasma cortisol and blood lactate also elevate significantly when fish are exposed to progressive hypoxia [52,79]. There are various physiological effects of nanoparticles dissolved in ambient water of fish. These nanoparticles can cause respiratory toxicity, disturbances of trace elements present in tissues and inhibits sodium and potassium ion ATPase [80]. Chronic exposure to sublethal level of "Fullerene aggregates" can result in oxidative stress resulting in inhibited growth in freshwater fish C. auratus [81]. There are studies showing an increase in haemoglobin and red blood cell (RBC) count in blood of fish exposed to hypoxia. Hypoxia also effects on adenosine triphosphate (ATP) production leading to a reduced production of ATP [82]. Exposure of freshwater $O$. mykiss to copper reduces the plasma concentration of sodium, potassium and calcium ions in fish and also results in increased secretion of mucus in gill, liver and kidney tissues [83]. Fish gill morphology is also markedly affected by chemical and physical irritants in the surrounding water (e.g. various toxicants, extremes of temperature or $\mathrm{pH}$ ). Histopathological studies have revealed gill lesions under such exposure which include changes in gill epithelium (lifting, necrosis, hyperplasia, hypertrophy, rupture), bulbing or fusing of gill lamellae, hypersecretion and proliferation of mucocytes, changes in chloride cells and gill vasculature [84]. Salinity changes in the ambient of fish can cause increased innate immune response and a depressed adaptive immune response in fish [85]. Some fish anaesthetics like benzocaine, 2-phenoxyethanol, MS-222 (Sandoz), metomidate, and carbon dioxide gas were also investigated in $O$. mykiss. A severe hypoxia developed with the cessation of breathing in deep anaesthesia which leads to a rise in the partial pressure of blood carbon dioxide, adrenaline concentration, and a fall in blood $\mathrm{pH}$ [86]. The haematological parameters were altered when fish were orally administered with 
gum Arabic showing significant changes in thrombocyte count [87]. The haematological parameters along with micronuclei induction and the pathological marker enzyme activities were greatly altered when $C$. punctatus were exposed to thermal power plant effluents containing heavy metals like $\mathrm{Fe}, \mathrm{Cu}, \mathrm{Zn}, \mathrm{Mn}, \mathrm{Ni}, \mathrm{Co}$ and $\mathrm{Cr}$ [88]. The plasma cortisol during stress elevates and plays an important role in upregulating pathways involved in energy-substrate mobilization including gluconeogenesis and simultaneously downregulates energy demanding pathways including growth and immune function [79]. Socially isolated $D$. rerio faces acute stress which can be evidenced physiologically by looking into the cortisol levels which is elevated in isolated fish compared to the grouped ones. Socially isolated fish also showed a decreased immune response compared to the grouped ones [89]. A recent study has reported that cortisol level elevates when an adult naive $D$. rerio is in contact with a stimulus fish (predator or non-predator) as compared to fish housed in visual contact with the stimulus fish [90]. One of the studies on D. rerio revealed that $\mathrm{Na}$ ion balance and hydrogen ion secretion is regulated during acid exposed to the fish [91].

\section{Cellular Defense Pathways under Oxidative Stress}

There are various signalling pathways associated to different situations under oxidative stress. For example, in hypoxic status, AMP-activated protein kinase (AMPK), mitogen activated protein kinase (MAPK), Nuclear factor erythroid 2-related factor 2/Kelch-likeECH-associated protein 1 (Nrf2/Keap1) and nuclear factor kappa-light-chain-enhancer of activated B cells (NFKB) play a prominent role in adaptation to hypoxia [92,93] (Fig. 1). A key transcriptional complex hypoxia inducing factor (HIF) has emerged as an important regulator of molecular hypoxic response that mediates a wide range of physiological and cellular mechanism needed to adapt to reduced oxygen [94].

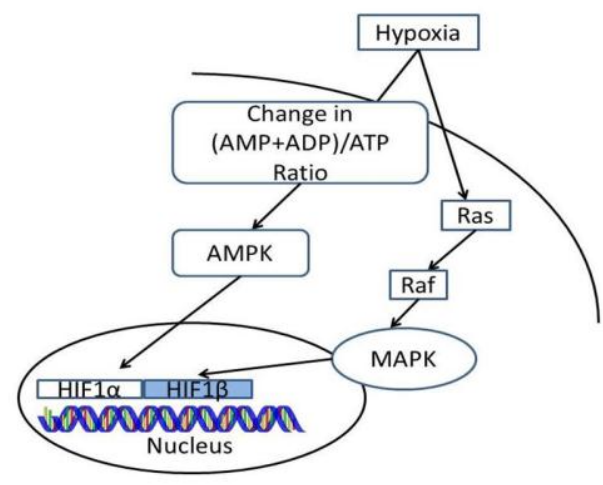

Fig. 1. Hypoxia induced metabolic pathways for expression of target genes via ATP/ADP+AMP ratio and Ras-Raf pathway activating HIFs to regulate expression of target genes. 
Ekambaram and Parasuraman [95] explained the role of fish adipocytes showing HIF1 $\alpha$ mediated Heme oxygenase-1 expression. In their study where fish adipocyte were subjected to hypoxic condition in an in vitro technique for $1 \mathrm{~h}$ and were analysed for the expression of adipokines, adipogenic transcription factors and anti-adipogenic markers in fish adipocytes. Elevation of asymmetric dimethylarginine, tumour necrosis factor alpha $(\mathrm{TNF} \alpha)$ and leptin along with decreased adiponectin, adipogenic transcription factors and altering sirtuins were observed. Craig et al. [96] showed that the acute exposure to $\mathrm{Cu}$ resulted significant increase in gene expression of cytochrome $\mathrm{C}$ oxidase subunit 17 (COX-17) and catalase, associated with both increased $\mathrm{Cu}$ load and protein carbonyl concentrations in the gill and liver after $48 \mathrm{~h}$. There were changes in the activities of cytochrome oxidase (COX) and citric synthase (CS), indicating possible alterations in cell oxidative capacity. Moreover, $\mathrm{Cu}$ affected $\mathrm{COX}$ to $\mathrm{CS}$ ratios in both gill and liver, suggesting that $\mathrm{Cu}$ alters normal mitochondrial biogenic processes, possibly through metallochaperones like COX-17. In the liver sample of some fish, an activation of transcription factor HIF was detected after acute cold exposure [97, 98]. Under a pollutant induced hypoxic condition there was a significant increase in the level of nuclear factor erythroid 2 (NRF2), HIF1 $\alpha$, heat shock protein 70 (HSP70), TNF $\alpha$ and NFkB and decrease in thiol status. HIF1 $\alpha$ triggers the elevation of HSP70 in response to hypoxia induced stress, which in turn evokes cytoprotective effect by favouring the survival mechanisms via the upregulation of kinases involved in pro-survival pathway (NFKB) and downregulation of $\mathrm{TNF} \alpha$, thereby enabling fish to tolerate and survive in a stressed environment [99,93] (Fig 2).

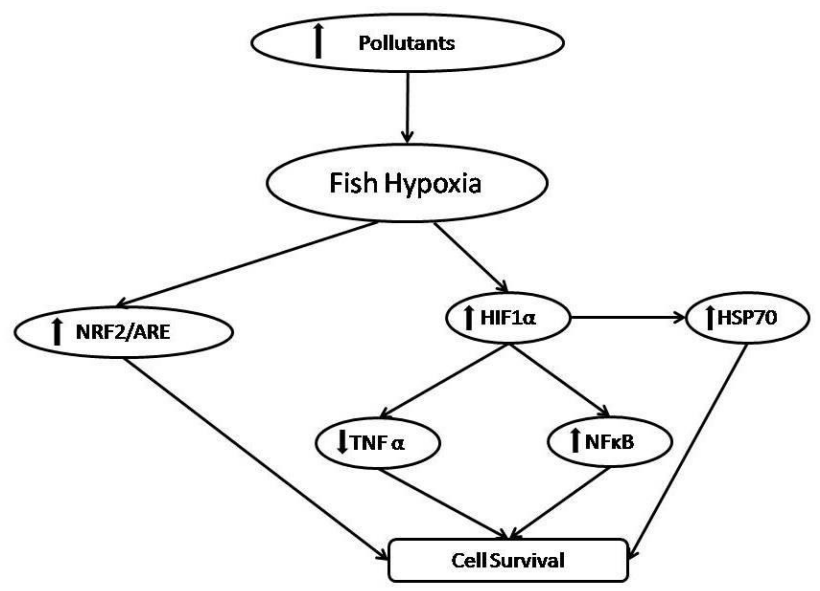

Fig. 2. Hypoxia induced NRF2/ARE pathway. The HIF1 $\alpha$ upregulates HSP70 and also inhibits inhibits TNF $\alpha$ to ensure cell survival. (Modified from reference [97] and [91]).

In both acute and chronic exposure to hypoxia in sea bass, the HIF1 $\alpha$ mRNA copies were significantly increased in the liver tissues [100]. Fish exposed to $\mathrm{Cu}$ stress causes increase in expression of nuclear factor erythroid 2-related factor (Nrf2), V-maf avian 
musculoaponeurotic fibrosarcoma oncogene homolog $\mathrm{G}$ (Maf G1) and protein kinase $\mathrm{C}$ delta type (PKCd) genes which suggests that synthesis of these factors are required for the induction of antioxidant genes [101]. Change in temperature induces expression of mitochondrial marker enzyme CS and COX. This stress showed increases in nuclear respiratory factor-1 (NRF-1) mRNA. In contrast, peroxisome proliferator-activated receptor alpha (PPAR- $\alpha$ ) mRNA levels were decreased in the experimental groups. Moreover, peroxisome proliferator-activated receptor gamma coactivator 1-alpha (PGC$1 \alpha)$ mRNA was not changed under this stress [102].

Olsvik et al. [103] showed that the transcript levels of few antioxidant enzymes like superoxide dismutase (SOD), catalase and glutathione peroxidase (GPx) and some stress proteins like (metallothionein, MT) varied in G. morhua when exposed to various ambient oxygen concentrations. The mRNA levels of two key antioxidant enzymes (GPx and glutathione S-transferase, GST) in Paralichthys olivaceus was increased when exposed to a change in salinity in their ambience [104]. Significant changes of antioxidant gene mRNA levels on heavy metal exposure to fish also disclosed the stress responsiveness of the fish. It was also showed that MT is a stress protein consisting of a sulfhydryl group which is mostly involved in heavy metal homeostasis and detoxification [105-107]. In $C$. auratus and salmo trutta, Hansen et al. [108] and Choi et al. [109] reported that the presence of $\mathrm{Cd}$ and $\mathrm{Zn}$ in the ambient water significantly increases the mRNA levels of MT, GPx, SOD, catalase and glutathione reductase (GR) in a dose and time dependent manner. Jin et al. [110] observed that when $D$. rerio were exposed to a very common pesticide called atrazine at various concentrations, there was a significant increase in the mRNA levels of SOD, catalase and GPx.

When a fish was exposed to $\mathrm{Cd}$ for $24 \mathrm{~h}$, it promoted enhanced expression of mitochondrial succinate dehydrogenase activity and PGC- $1 \alpha$ suggesting Cd induced stress involvement of PGC- $1 \alpha$ in fish and it may be associated with mitochondrial function [111]. At low ambient temperature, expression of senescence associated $\beta$-galactosidase, lipofuscin and adenosine diphosphate (ADP)/ATP ratio were reduced compared to those reared at high and moderate temperatures, whereas catalase activity, Mn-superoxide dismutase activities, mitochondrial membrane potential and the levels of ATP, ADP, sirtuin 1 (SIRT1) and Forkhead box $\mathrm{O}$ expression were elevated. It can be said that cellular metabolism, energy utilization and gene expression are altered at lower ambient temperature, which is associated with the extension of lifespan of the annual fish [112]. In a study of salinity stress in Scophthalmus maximus, AMPK $\alpha 1$ and $\alpha 2$ genes could be detected in all tested tissues indicating that they are constitutively expressed and significantly altered the gene expression levels of AMPK $\alpha 1$ and $\alpha 2$ mRNA in gill tissues, thereby suggesting that AMPK $\alpha 1$ and $\alpha 2$ played important roles in mediating the salinity stress in S. Maximus [113].

It is observed that ability to reduce metabolic rate in a fish exposed to hypoxic condition is an important component to enhance survivability resulting in reduced energy expenditure. It is studied that hypoxic state leads to significant lowering of ATP production in the cells of the fish to enhance their survivability $[114,115]$. 


\section{Conclusion and Future Research}

A huge number of toxicological studies have evidenced that various chemicals in the aquatic environment can unfavourably affect all the aquatic organisms, including fish. Not only the chemicals but the rapidly changing aquatic ambience and abruptly changing climate also affect the aquatic organisms by changing their physiology and biochemical aspects. These environmental stressors can even disrupt the various developmental processes like deformities in the embryo during embryonic development and other developmental stages like larva and fry. So, it can be said that both chemotoxic and altered environmental ambience can affect the physiology of the fish by altering the hormonal secretion like cortisol. A summary of such affects has been shown in Fig 3 .

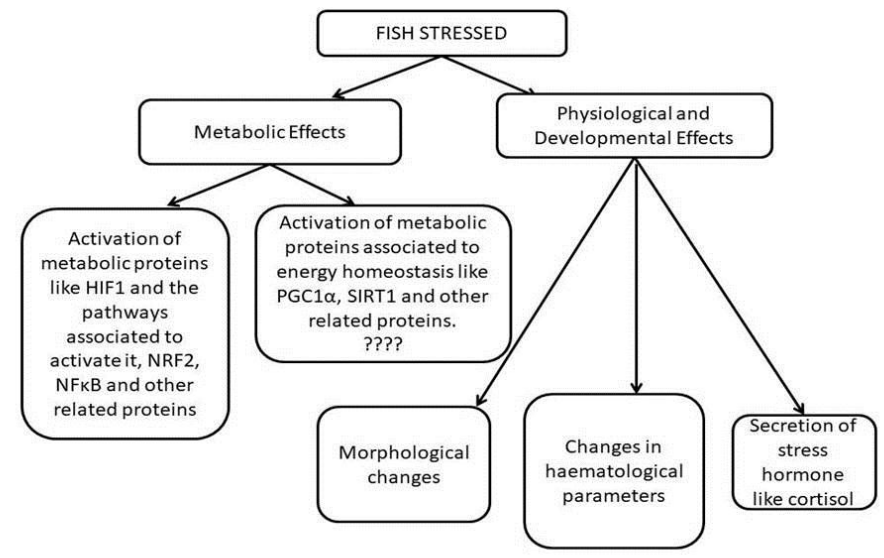

This is now known that fish in altered ambient is triggered with expression of various factors like HIF1, NRF2 and many more metabolic proteins involving them in several signalling pathways. Although metabolic pathways involved in the energy homeostasis and ATP production has been addressed to some extent in case of temperature and salinity stress exposure under metabolic effects, it needs further analysis of these metabolic proteins under variable environmental stressors.

\section{Acknowledgment}

Provision of research facilities by Department of Zoology, Visva-Bharati, West Bengal is hereby acknowledged. 


\section{References}

1. J. G. Scandalios, Braz. J. Med.Biol. Res. 38, 995 (2005). http://dx.doi.org/10.1590/S0100$\underline{\text { 879X2005000700003 }}$

2. E. Birben, U. M. Sahiner, C. Sackesen, S. Erzurum, and O. Kalayci, World. Allergy Organ. J. 5, 82 (2012). https://doi.org/10.1016/j.fct.2013.02.041

3. S. Noori, Open Access Sci. Rep. 1, Article ID 413 (2012). http://dx.doi.org/10.4172/scientificreports.413

4. V. I. Lushchak, Aquat. Toxicol. 101, 13 (2011). https://doi.org/10.1016/j.aquatox.2010.10.006

5. D. J. Betteridge, Metabolism 49, 3 (2000). https://doi.org/10.1016/S0026-0495(00)80077-3

6. B. Halliwell and O. I. Arouma, FEBS. Lett. 281, 9 (1991). https://doi.org/10.1016 0014$\underline{\text { 5793(91)80347-6 }}$

7. M. R. Dutordoir and D. A. A. Bates, Biochimica. Et. Biophysica. Acta 1863, 2977 (2016). https://doi.org/10.1016/j.bbamcr.2016.09.012

8. H. Seis, Angew. Chem. Int. Ed. Engl. 25, 1058 (1986). https://doi.org/10.1002/anie.198610581

9. J. M. Mates, Toxicology 153, 83 (2000). https://doi.org/10.1016/S0300-483X(00)00306-1

10. J. Finaud, G. Lac, and E. Filaire, Sports. Med. 36, 327 (2012).

11. A. Valavanidis, T. Vlahogianni, M. Dassenakis, and M. Scoullos, Ecotoxicol. Environ. Safety 64, 178 (2006). https://doi.org/10.1016/j.ecoenv.2005.03.013

12. D. R. Livingstone, Revue. De. Med. Vet. 6, 427 (2003).

13. C. Harper and J. C. Wolf, ILAR J. 50, 387 (2009). https://doi.org/10.1093/ilar.50.4.387

14. M. Javed, I. Ahmad, N. Usmani, and M. Ahmad, Ecotoxicol. Environ. Safety 127, 163(2016). https://doi.org/10.1016/j.ecoenv.2016.01.007

15. N. Braun and A. P. O. Nuner, Aquaculture 301, 22 (2010). https://doi.org/10.1016/j.aquaculture.2010.01.022

16. S. Fontagne-Dicharry, S. Godin, H. Liu, and P. A. J. Prabhu, Br. J. Nutr. 113, 1876(2015). https://doi.org/10.1017/S0007114515001300

17. G. Wobeser, J. Fish. Res. Board. Canada 32, 2005 (1975). https://doi.org/10.1139/f75-236

18. Y. Sadovy, J. Fish. Biol. 59, 90 (2005). https://doi.org/10.1111/j.1095-8649.2001.tb01381.x

19. C. B. Schreck, W. Contreras-Sanchez, and M. S. Fitzpatrick, Aquaculture 197, 3(2001). https://doi.org/10.1016/B978-0-444-50913-0.50005-9

$20 . \quad$ B. Zhou, W. Liu, W. H. L. Siu, D. Toole, P. K. S. Lama, and R. S. S. Wu, Aquat. Toxicol. 77, 136 (2006). https://doi.org/10.1016/j.aquatox.2005.11.006.

21. S. D. Gerking, Environ. Physiol. Fishes 35, 569 (1980).

22. R. V. Oost, J. Beyer, and N. P. E. Vermeulen, Environ. Toxicol. Pharmacol. 13, 57 (2003).

23. A. Slaninova, M. Smutna, H. Modra, and Z. Svobodova, Neuro Endocrinol. Lett. 30, 2 (2009).

24. M. B. Fonseca, L. Glusczak, B. S. Moraes, C. Menezes, A. Pretto, M. A. Tierno, R. Zanella, F. F. Gonc-alves, and V. L. Loro, Ecotoxicol. Environ. Safety 69, 416 (2008). https://doi.org/10.1016/j.ecoenv.2007.08.006

25. E. Osioma, M. A. Akanji, and R. O. Arise, World Appl. Sci. J. 26, 508 (2013).

26. R. Vinodhini and M. Narayanan, Iran. J. Environ. Health. Sci. Eng. 6, 73 (2008).

27. M. Javed, M. I. Ahmad, N. Usmani, and M. Ahmad, Sci. Rep. 7, Article ID 1675 (2017). https://doi.org/10.1038 s41598-017-01749-6

28. J. A. Almeida, R. E. Barreto, E. L. B. Novelli, F. J. Castro, and S. E. Moron, Neotrop. Ichthyol. 7, 103 (2009). http://dx.doi.org/10.1590/S1679-62252009000100013

29. A. C. Bhowmick, R. R. Bhowmick, and M. I. Moim, J. Sci. Res. 10, 25 (2018). http://dx.doi.org/10.3329/jsr.v10i1.32134

30. M. Aureliano, N. Joaquim, A. Sousa, H. Martins, and J. M. Coucelo, J. Inorg. Biochem. 90, 159 (2002). https://doi.org/10.1016/S0162-0134(02)00414-2 
31. J. Blahova, L. Plhalova, M. Hostovsky, L. Divisova, R. Dobsikova, I. Mukulikova, S. Stepanova, and Z. Svobodova, Food. Chem. Toxicol. 61, 82 (2013). https://doi.org/10.1016/j.fct.2013.02.041

32. M. Faheem, N. Jahan, and K. P. Lone, J. Anim. Plant. Sci. 26, 514 (2016).

33. S. Tao, Y. Zhang, C. Yuan, J. Gao, F. Wu and Z. Wang, Ecotoxicol. Environ. Safety 124, 377 (2016). https://doi.org/10.1016/j.ecoenv.2015.11.014

34. E. S. Botte, D. R. Jerry, S. C. King, C. S. Keune, and A. P. Negri, Marine Poll. Bull. 65, 384 (2012). https://doi.org/10.1016/j.marpolbul.2011.08.020

35. J. E. Choi, S. Kim, J. H. Ahn, P. Youn, J. S. Kang, K. Park, J. Yi, and D. Y. Ryu, Aquat. Toxicol. 100, 151 (2010). https://doi.org/10.1016/j.aquatox.2009.12.012

36. D. G. Costa-Silva, M. E. M Nunus, G. L. Wallau, I. K. Martins, A. P. P. Zemolin, L. C. Cruz, N. R. Rodrigues, A. R. Lopes, T. Posser, and J. L. Franco, Environ. Sci. Pollut. Res. Int. 22, 15526 (2015). https://doi.org/10.1007/s11356-015-4737-7

37. S. A. Dar, A. R. Yousuf, M. H. Balkhi, and M. N. Ali, Toxicol. Environ. Chem. 96, 906 (2014). https://doi.org/10.1080/02772248.2014.982122

38. S. A. Dar, A. R. Yousuf, M. H. Balkhi, F. A. Ganai, and F. A. Bhat, Chemosphere 120, 273 (2015). https://doi.org/10.1016/j.chemosphere.2014.07.031

39. M. Fatima, N. Usmani, F. Firdaus, M. F. Zafeer, S. Ahmad, K. Akhtar, S. M. D. Husain, M. H. Ahmad, E. Anis, and M. Hossain, Comp. Biochem. Physiol. Part C: Toxicol. Pharmacol. 176, 17 (2015). https://doi.org/10.1016/j.cbpc.2015.07.004

40. S. Ganesan, N. A. Thirumurthi, A. Raghunath, S. Vijayakumar, and E. Perumal, J. Appl. Toxicol. 36, 554 (2015). https://doi.org/10.1002/jat.3224

41. M. M. Hegazi, Z. I. Attia, and O. A. Ashour, Aquat. Toxicol. 99, 118 (2010). https://doi.org/10.1016/j.aquatox.2010.04.007

42. O. I. Kubrak, O. V. Lushchak, J. V. Lushchak, I. M. Torous, J. M. Storey, K. B. Storey, and V. I. Lushchak, Comp. Biochem. Physiol. Part C: Toxicol. Pharmacol. 152, 360 (2010). https://doi.org/10.1016/j.cbpc.2010.06.003

43. D. Mohanty and L. Samanta, Chemosphere 155, 28 (2016). https://doi.org/10.1016/j.chemosphere.2016.04.035

44. C. D. Nwani, N. S. Nagpure, R. Kumar, B. Kushwaha, and W. S. Lakra, Environ. Toxicol. Pharmacol. 36, 539 (2013). https://doi.org/10.1016/j.etap.2013.06.001

45. S. Pandey, S. Parvez, I. Sayeed, R. Haque, B. Bin-Hafeez, and S. Raisuddin, Sci. Total Environ. 309, 105 (2003). https://doi.org/10.1016/S0048-9697(03)00006-8

46. S. Parvez and S. Raisuddin, Environ. Toxicol.Pharmacol. 20, 112 (2005). https://doi.org/10.1016/j.etap.2004.11.002

47. I. Sayeed, S. Parvez, S. Pandey, B. Bin-Hafeez, B. Haque, and S. Raisuddin, Ecotoxicol. Environ. Safety 56, 295 (2003). https://doi.org/10.1016/S0147-6513(03)00009-5

48. S. S. Soares, H. Martins, C. Gutiérrez-Merino, and M. Aureliano, Comp. Biochem. Physiol. Part C: Toxicol. Pharmacol. 147, 168 (2008). https://doi.org/10.1016/j.cbpc.2007.09.003

49. G. L. Allan and G. B. Maguire, Aquaculture 94, 27 (1991). https://doi.org/10.1016/0044$\underline{\text { 8486(91)90126-R }}$

50. E. Baroudy and J. M. Elliott, J. Fish Biol. 44, 736 (1994). https://doi.org/10.1111/j.1095$\underline{8649.1994 . t b 01250 . x}$

51. C. A. Caldwell and J. Hinshaw, Aquaculture 126, 183 (1994). https://doi.org/10.1016/0044$\underline{8486(94) 90259-3}$

52. N. A. Herbert and J. F. Steffensen, Mar. Biol. 147, 1403 (2005). https://doi.org/10.1007/s00227-005-0003-8

53. A. M. Loong, S. F. Ang, W. P. Wong, H. O. Portner, C. Bock, R. Wittig, C. R. Bridges, S. F. Chew, and Y. K. Ip, J. Comp. Physiol. B 178, 853 (2008). https://doi.org/10.1007/s00360008-0273-9

54. V. I. Lushchak, T. V. Bagnyukova, V. V. Husak, L. I. Luzhna, O. V. Lushchak, and K. B. Storey, Int. J. Biochem. Cell. Biol. 37, 1670 (2005). https://doi.org/10.1016/j.biocel.2005.02.024 
55. N. L. Quinn, C. R. McGowan, G. A. Cooper, B. F. Koop, and W. S. Davidson, Physiol. Genomics. 43, 1056 (2011). https://doi.org/10.1152/physiolgenomics.00090.2011

56. R. Triebskorn, H. Kohler, W. Honnen, M. Schramm, S. M. Adams, and E. F. Muller, J. Aquat. Ecosyst. Stress Recovery 6, 57 (1997). https://doi.org/10.1023 A 1008224301117

57. E. G. Martins, S. G. Hinch, D. A. Patterson, M. J. Hague, S. J. Cooke, K. M. Miller, M. F. Lapointe, K. English, and A. P. Farrell, Global. Change Biol. 17, 99 (2010). https://doi.org/10.1111/j.1365-2486.2010.02241.x

58. R. L. Malek, H. Sajadi, J. Abraham, M. A. Grundy, and G. S. Gerhard, Comp. Biochem. Physiol. 138, 363 (2004). https://doi.org/10.1016/j.cca.2004.08.014

59. C. Vinagre, D. Madeira, L. Narciso, H, N. Cabral, and M. Diniz, Ecol. Indic. 23, 274 (2012). https://doi.org/10.1016/j.ecolind.2012.04.009

60. P. O. Fromm, Environ. Biol. Fishes 5, 79 (1980). https://doi.org/10.1007_BF00000954

61. P. C. Das, S. Ayyappan, and J. K. Jena, Aquaculture 256, 80 (2006). https://doi.org/10.1016/j.aquaculture.2006.02.019

62. W. Mai, J. Yan, L. Wang, Y. Zheng, Y. Xin, and W. Wang, Aquat. Toxicol. 100, 271 (2010). https://doi.org/10.1016/j.aquatox.2010.07.025

63. N. Masson, F. Guerold, and O. Dangles, Chemosphere 47, 467 (2002). https://doi.org/10.1016/S0045-6535(02)00055-3

64. M. M. Zahangir, F. Haque, and G. M. Mostakim, Aquacult. Rep. 2, 91 (2015). https://doi.org/10.1016/j.aqrep.2015.08.008

65. X. Zhu, L. Zhu, Y. Li, Z. Duan, W. Chen, and P. J. J. Alvarez, Environ. Toxicol. Chem. 26, 976 (2007). https://doi.org/10.1897/06-583.1

66. X. Shi, A. Gu, G. Ji, Y. Li, J. Di, J. Jin, F. Hu, Y. Long, Y. Xia, C. Lu, L. Song, S. Wang, and X. Wang, Chemosphere. 85, 1010 (2011). https://doi.org/10.1016/j.chemosphere.2011.07.024

67. D. G. Sfakianakis, E. Renieri, M. Kentouri, and A. M. Tsatsakis, Environ. Res. 137, 246 (2015). https://doi.org/10.1016/j.envres.2014.12.014

68. B. Jezierska, K. Ługowska, and M. Witeska, Fish. Physiol. Biochem. 35, 625 (2008). https://doi.org/10.1007/s10695-008-9284-4

69. W. Dong, J. Liu, L. Wei, Y. Jingfeng, M. Chernick, and D. E. Hinton, Peer. J. 4, Article ID 2282 (2016). http://doi.org/10.7717/peerj.2282

70. V. P. Palace, J. E. Spallholz, J. Holm, K. Wautier, R. E. Evans, and C. L. Baron, Ecotoxicol. Environ. Safety 58, 17 (2004). https://doi.org/10.1016/j.ecoenv.2003.08.019

71. J. Holm, V. Palace, P. Siwik, G. Sterling, R. Evans, C. Rbaron, J. Werner, and K. Wautier, Environ. Toxicol. Chem. 24, 2373 (2009). https://doi.org/10.1897/04-402R1.1

72. P. - J. Chen, W. -L. Wu, and K. C. -W. Wu, Water. Res. 47, 3899 (2013). https://doi.org/10.1016/j.watres.2012.12.043

73. H. Xu, X. Shao, Z. Zhang, Y. Zou, and L. Liuqing Yang, Ecotoxicol. Environ. Safety 93, 39 (2013). https://doi.org/10.1016/j.ecoenv.2013.03.038

74. B. A. Barton and G. K. Zwama, Annu. Rev. Fish. Dis. 1, 3 (1991). https://doi.org/10.1016/0959-8030(91)90019-G

75. B. A. Barton, C. B. Schreck, A. Linda, and L. A. Sigismond, T. Am. Fish. Soc. 115, 245 (1986). https://doi.org/10.1577/1548-8659(1986)115\%3C245:MADECP\%3E2.0.CO;2

76. B. A. Barton, G. S. Weiner, and C. B. Schreck, Can. J. Fish. Aquat. Sci. 42, 710 (1985). https://doi.org/10.1139/f85-091

77. C. C. Woodward and R. J. Strange, Trans. Am. Fish. Soc. 116, 574 (1987). https://doi.org/10.1577/1548-8659(1987)116\%3C574:PSRIWA\%3E2.0.CO;2

78. F. D. F. Sampaio and C. A. Freire, Fish Fisheries 17, 1055 (2016). https://doi.org/10.1111/faf.12158

79. E. Faught and M. M. Vijayan, Comp. Biochem. Physiol. 199, 136 (2016). https://doi.org/10.1016/j.cbpb.2016.06.012

80. B. J. Shaw and R. D. Handy, Environ. Int. 37, 1083 (2011). https://doi.org/10.1016/j.envint.2011.03.009 
81. X. Zhu, L. Zhu, Y. Lang, and Y. Chen, Environ. Toxicol. Chem. 27, 1979 (2009). https://doi.org/10.1897/07-573.1

82. M. S. Pollock, L. M. J. Clarke, and M. G. Dube, Environ. Rev. 15, 1 (2007). https://doi.org/10.1139/a06-006

83. L. Pilgaard, H. Malte, and F. B. Jensen, Aquat. Toxicol. 29, 197 (1994). https://doi.org/10.1016/0166-445X(94)90068-X

84. J. Mallatt, Can. J. Fish. Aquat. Sci. 42, 630 (2011). https://doi.org/10.1139/f85-083

85. D. L. Makrinos and T. J. Bowden, Fish Shellfish Immunol. 53, 50 (2016). https://doi.org/10.1016/j.fsi.2016.03.008

86. G. K. Iwama, J. C. McGeer, and M. P. Pawluk, Can. J. Zool. 67, 2065 (1989). https://doi.org/10.1139/z89-294

87. C. Faggio, F. Fazio, S. Marafioti, F. Arfuso, and G. Piccione, Iran. J. Fish. Sci. 14, 60 (2015).

88. M. Javed, I. Ahmad, A. Ahmad, N. Usmani, and M. Ahmad, Springer Plus 5, Article ID 761 (2016). https://doi.org/10.1186/s40064-016-2478-9

89. M. M. Forsatkar, O. Safar, and C. Boiti, Acta Ethologica 20, 255 (2017).

90. M. S. Abreu, T. A. Oliveira, G. Koakoski, R. E. Barreto, and L. J. B. Barcellos, Zebrafish 15, 228 (2018). https://doi.org/10.1089/zeb.2017.1509

91. R. W. M. Kwong, Y. Kumai, and S. F. Perry, J. Exp. Biol. 217, 651 (2014). https://doi.org/10.1242/jeb.091603.

92. C. Zhu, Z. Wang, and B. Yan, J. Comp. Physiol. B 183, 1005 (2013). https://doi.org/10.1007/s00360-013-0762-3

93. J. Yin, W. Ren, X. Wu, G. Yang, J. Wang, T. Li, J. Ding, L. Cai, and D. Su, J. Food Agric. Environ. 11, 132 (2013).

94. A. Weidemann and R. S. Johnson, Cell Death Differ. 15, 621 (2008). https://doi.org/10.1038/cdd200812

95. P. Ekambaram and P. Parasuraman, Biol. Open 7, 1375 (2017). https://doi.org/10.1242/bio.027334

96. P. M. Craig, C. M. Wood, and G. B. McClelland, Am. J. Physiol. Regul. Integr. Comp. Physiol. 293, R1882 (2007). https://doi.org/10.1152/ajpregu.00383.2007

97. K. Heise, M. S. Estevez, S. Puntarulo, M. Galleano, M. Nikinmaa, H. O. Portner, and D. Abele, J. Comp. Physiol. 77, 765 (2007). https://doi.org/10.1007/s00360-007-0173-4

98. K. Heise, S. Puntarulo, M. Nikinmaa, M. Lucassen, H. Portner, and D. Abele, Comp. Biochem. Physiol. 143, 494 (2006). https://doi.org/10.1016/j.cbpa.2006.01.014

99. E. Padmini, N. Meenakshi, and P. Parimala, J. Pharmacy Res. 9, 491 (2015).

100. G. Terova, S. Rimoldi, S. Cora, G. Bernardini, R. Gornati, and M. Saroglia, Aquaculture 279, 150 (2008). https://doi.org/10.1016/j.aquaculture.2008.03.041

101. W. Jiang, Y. Liu, K. Hu, J. Jiang, S. Li, L. Feng, and X. Zhou, Aquat. Toxicol. 155, 301 (2014). https://doi.org/10.1016/j.aquatox.2014.07.003

102. G. B. McClelland, P. M. Craig, K. Dhekney, and S. Dipardo, J. Physiol. 577, 739 (2006). https://doi.org/10.1113/jphysiol.2006.119032

103. P. A. Olsvik, T. Kristensen, R. Waagbo, K.-E.Tollefsen, B. O. Rosseland, and H. Toften, J. Exp. Biol. 209, 2893(2006). https://doi.org/10.1242/jeb.02320

104. C. Y. Choi, K. W. An, and M. I. An, Comp. Biochem. Physiol. 149, 330 (2008). https://doi.org/10.1016/j.cbpa.2008.01.013

105. A. Viarengo, B. Burlando, M. Cavaletto, B. Marchi, E. Ponzano, and J. Blasco, Regul. Intigr. Comp. Physiol. 46, 606 (1999). https://doi.org/10.1016/S0141-1136(98)00096-8

106. B. H. Hansen, S. Romma, O. A. Garmo, P. A. Olsvik, and R. A. Andersen, Comp. Biochem. Physiol. 143, 263 (2006). https://doi.org/10.1016/j.cbpc.2006.02.010

107. M. Banni, L. Chouchene, K. Said, A. Kerkeni, and I. Messaoudi, BioMetals 24, 981 (2011). https://doi.org/10.1007/s10534-011-9456-z

108. B. H. Hansen, S. Romma, O. A. Garmo, S. A. Pedersen, P. A. Olsvik, and R. A. Andersen, Chemosphere 67, 2241 (2007). https://doi.org/10.1016/j.chemosphere.2006.12.048 
109. C. Y. Choi, K. W. An, E. R. Nelson, and H. R. Habibi, Comp. Biochem. Physiol. Part C: Toxicol. Pharmacol. 145, 595 (2007). https://doi.org/10.1016/j.cbpc.2007.02.007

110. Y. Jin, X. Zhang, L. Shu, L. Chen, L. Sun, H. Qian, W. Liu, and Z. Fu, Chemosphere 78, 846 (2010). https://doi.org/10.1016/j.chemosphere.2009.11.044

111. Y. Zhao, L. Ruiwen, and Y. Lin, Turk. J. Fish. Aquat. Sci. 16, 839 (2016). https://doi.org/10.4194/1303-2712-v16_4_10

112. C. -Y. Hsu and Y. -C. Chiu, Aging. Cell 8, 726 (2009). https://doi.org/10.1111/j.14749726.2009.00525.X

113. L. Zeng, B. Liu, C. Wu, J. Lei, M. Xu, A. Zhu, J. Zhang, and W. Hong, Fish Physiol. Biochem. 42, 1595 (2016). https://doi.org/10.1007/s10695-016-0243-1

114. V. I. Lushchak and T. V. Bagnyukova, Comp. Biochem. Physiol. Part B: Biochem. Mol. Biol. 148, 390 (2007). https://doi.org/10.1016/j.cbpb.2007.07.007

115. J. G. Richards, J. Exp. Biol. 214, 191 (2011). https://doi.org/10.1242/jeb.047951 